\title{
Air quality assessment for Portugal
}

\author{
A. Monteiro ${ }^{\text {a }}$, A.I. Miranda ${ }^{\mathrm{a}, *}$, C. Borrego ${ }^{\mathrm{a}}$, R. Vautard $^{\mathrm{b}}$ \\ ${ }^{a}$ CESAM, Departmento de Ambiente e Ordenamento, Universidade de Aveiro, 3810-193 Aveiro, Portugal \\ ${ }^{\mathrm{b}}$ LSCE/IPSL, Laboratoire CEA/CNRS/UVSQ, Gif sur Yvette, France
}

Received 25 February 2006; received in revised form 15 September 2006; accepted 5 October 2006

\begin{abstract}
According to the Air Quality Framework Directive, air pollutant concentration levels have to be assessed and reported annually by each European Union member state, taking into consideration European air quality standards. Plans and programmes should be implemented in zones and agglomerations where pollutant concentrations exceed the limit and target values. The main objective of this study is to perform a long-term air quality simulation for Portugal, using the CHIMERE chemistry-transport model, applied over Portugal, for the year 2001. The model performance was evaluated by comparing its results to air quality data from the regional monitoring networks and to data from a diffusive sampling experimental campaign. The results obtained show a modelling system able to reproduce the pollutant concentrations' temporal evolution and spatial distribution observed at the regional networks of air quality monitoring. As far as the fulfilment of the air quality targets is concerned, there are excessive values for nitrogen and sulfur dioxides, ozone also being a critical gaseous pollutant in what concerns hourly concentrations and AOT40 (Accumulated Over Threshold $40 \mathrm{ppb})$ values.
\end{abstract}

(C) 2006 Elsevier B.V. All rights reserved.

Keywords: Air quality; Numerical modelling; European legislation; Gas pollutants

\section{Introduction}

Air quality is one of the areas in which Europe has been most active in recent years. The European Commission (EC) defined an overall strategy through the setting of long-term air quality objectives. A series of directives has been introduced to control levels of certain pollutants and to monitor their concentrations in the air. In 1996, the Environment Council adopted the Framework Directive 96/62/EC (FWD) on ambient air quality assessment and management. This directive

\footnotetext{
* Corresponding author. Tel.: +351 234370200; fax: +351 234 429290.

E-mail address: aicm@dao.ua.pt (A.I. Miranda).
}

covers the revision of previously existing legislation and introduces new air quality standards for previously unregulated air pollutants, setting the timetable for the development of daughter directives for a range of pollutants. The list of atmospheric pollutants to be considered includes sulfur dioxide $\left(\mathrm{SO}_{2}\right)$, nitrogen dioxide $\left(\mathrm{NO}_{2}\right)$, particulate matter, lead, ozone $\left(\mathrm{O}_{3}\right)$, and benzene, carbon monoxide (CO), polyaromatic hydrocarbons, and some heavy metals.

The FWD was followed by the daughter directives, which establish the numerical limit values, or, in the case of ozone, target values, for each of the identified pollutants. Besides setting air quality limit and alert thresholds, the objectives of the daughter directives are to harmonize monitoring strategies, measuring methods, 
calibration, and quality assessment methods to arrive at comparable measurements throughout the European Union (EU) and to provide good public information.

In terms of ambient air quality assessment, the FWD also introduces new guidelines, identifying modelling as an air quality management tool and defining that ambient air quality, throughout the territory of the member states, shall be assessed by a combination of measurements and modelling techniques to provide an adequate level of information on ambient air quality in respect to the relevant pollutants. In fact, measured concentrations available at given monitoring sites do not generally describe sufficiently the spatial distribution of air pollutants over wide areas, whereas this information is a crucial factor to evaluate the impact of air pollution on human health and natural ecosystems. Modelling systems can represent suitable tools for these purposes, allowing the study of air quality with an adequate spatial detail, the verification of the fulfilment of the limit targets and threshold values imposed by the EC directives, and also the assessment of appropriate emission reduction strategies.

Therefore, to assess the air quality at a regional level, verifying the fulfilment of the limit targets and threshold values imposed by the EC directives, and to understand the causes and origin of air pollution, numerical modelling exercises should be used. Recent works (Hogrefe et al., 2001) emphasize the importance of policy analysis on a "climatological" basis rather than of focusing on a single critical episode; this approach allows to better evaluate the model performances and to quantify policies effects with respect to long-term air quality standards. Several ozone modelling studies were already performed for Portugal, in $\beta$-mesoscale domains and during some specific and episode days (e.g., Barros et al., 2003; Borrego et al., 2000). Large-scale simulations including Portugal have also been done, but with a coarse grid resolution (Coutinho and Borrego, 1991). The present work represents an important and a pioneer scientific air pollution modelling study for Portugal, because it aims to assess the air quality over the whole continental region of Portugal for the most critical gaseous pollutants $\left(\mathrm{SO}_{2}, \mathrm{CO}, \mathrm{NO}_{2}\right.$ and $\left.\mathrm{O}_{3}\right)$ and during the entire year of 2001, using a modelling system that was evaluated taking into account the EC Modelling Quality Objectives.

\section{Methodology}

CHIMERE is a 3D chemistry-transport model, based on the integration of the continuity equation for the concentrations of several chemical species in each cell of a given grid (Schmidt et al., 2001). CHIMERE has been used for several research applications, including sensitivity to anthropogenic or biogenic emissions (e.g., Beekmann and Derognat, 2003; Menut, 2003; Derognat et al., 2003), emission diagnostics (Vautard et al., 2003), or photo-oxidant forecasting over several regions of Europe (namely Italy and Belgium), being the official model for air quality forecasting over France and Paris region (Vautard et al., 2000). Results showed a reasonable skill for daily maximum forecasts of ozone with an averaged root mean square (RMS) error of about $10 \mathrm{ppb}$ and 0.8 of correlation, which is in agreement with the ozone forecast model intercomparison experiment described in Tilmes et al. (2002). Besides this

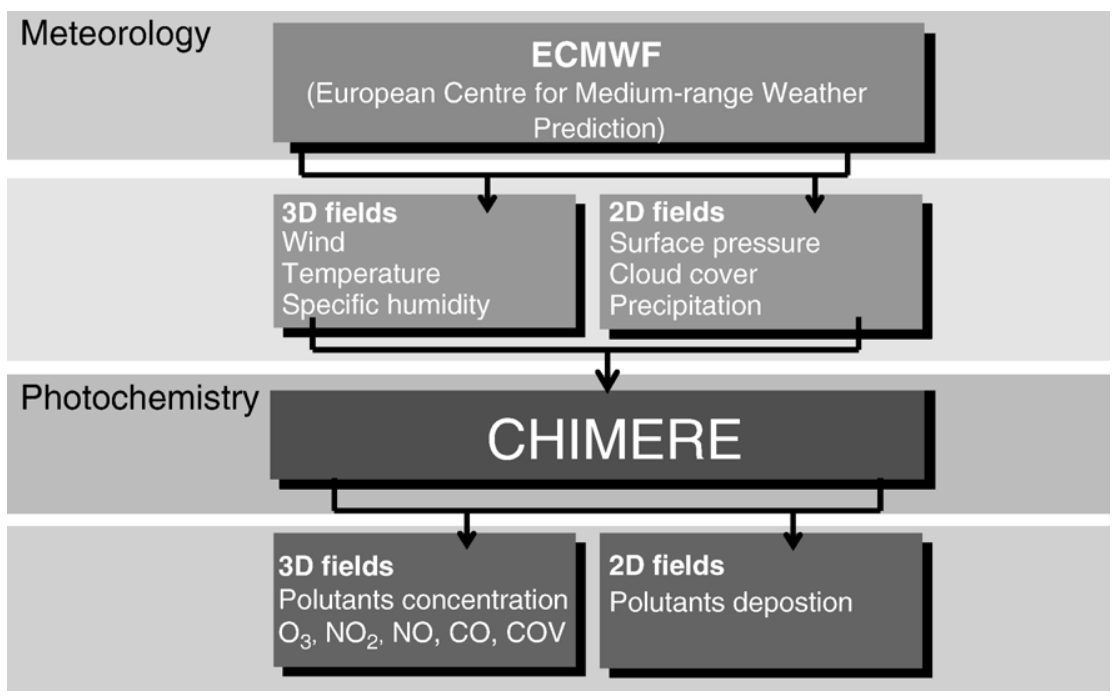

Fig. 1. Structure of the modelling system. 
a)

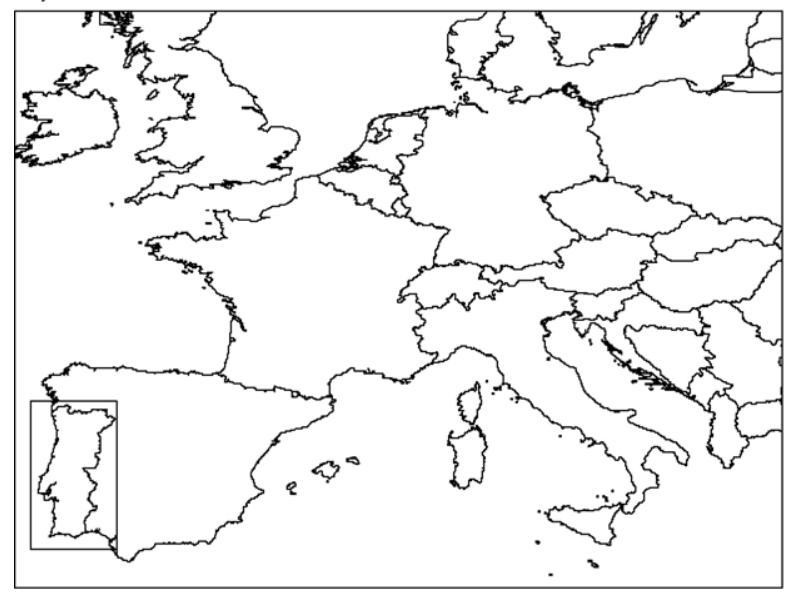

b)

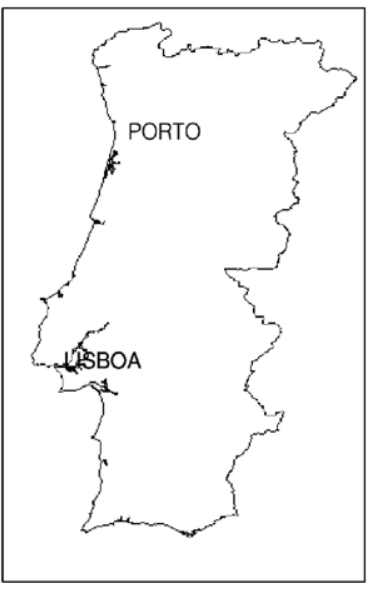

Fig. 2. Geographical domains used by the CHIMERE model.

proposed assessment task, this modelling system is being also applied in real-time air quality forecasting over Portugal (Monteiro et al., 2005a). The model version used here is primarily described in Schmidt et al. (2001), and further updates, especially for the smallerscale version, can be found in Vautard et al. (2003). The meteorological input variables are taken, as in Schmidt et al. (2001), from the European Centre for Mediumrange Weather Forecast (ECMWF): 3D fields of horizontal wind, temperature, specific humidity, cloud liquid water content, and 2D fields of surface pressure, heat fluxes, $2 \mathrm{~m}$ temperature and cloud cover, with different resolutions according to the domain of simulation $(36 \times 36 \mathrm{~km}$ for the European domain and $9 \times 9 \mathrm{~km}$ resolution for the Portugal domain). They are linearly interpolated to the CHIMERE grid, and linear time interpolation is also applied to obtain hourly values, along 2001. Besides the meteorological input, the CHIMERE model needs boundary and initial conditions, emission data, and the land use and topography characterization. The choice of year 2001 was conditioned by the last revised national emission inventory availability. In addition, CHIMERE simulations do not yet include forest fires emissions; therefore 2001 was considered a reliable period to simulate because it was not a critical year in terms of forest fires. Fig. 1 presents a simplified scheme of the CHIMERE model and its inputs/outputs.

The model was applied first to a continental scale (from $10.5^{\circ} \mathrm{W}$ to $22.5^{\circ} \mathrm{E}$ and $35^{\circ} \mathrm{N}$ to $57.5^{\circ} \mathrm{N}$, see Fig. 2a) and then to Portugal, as shown in Fig. 2b, using the same physics and a simple one-way technique. The second simulation (Portugal domain) was performed with a horizontal domain of $290 \mathrm{~km} \times 580 \mathrm{~km}$ and a
$10 \mathrm{~km}$ horizontal resolution (using the ECMWF data with $9 \times 9 \mathrm{~km}$ resolution) and the vertical grid consisted of six hybrid sigma-pressure layers with a model top at $700 \mathrm{hPa}$. The top altitudes of the layers vary with time, but their approximate values are, from bottom to top: 50 , $250,600,1200,2000$, and $3000 \mathrm{~m}$.

Lateral and top boundaries for the large-scale run are obtained by the MOZART second-generation model monthly climatology (Horowitz et al., 2005) as described in Monteiro et al. (2005b). As regards emissions, the CHIMERE model requires the input of 15 primary compounds: $\mathrm{NO}, \mathrm{NO}_{2}, \mathrm{HONO}, \mathrm{SO}_{2}, \mathrm{CO}$, ethane, $n$-butane,
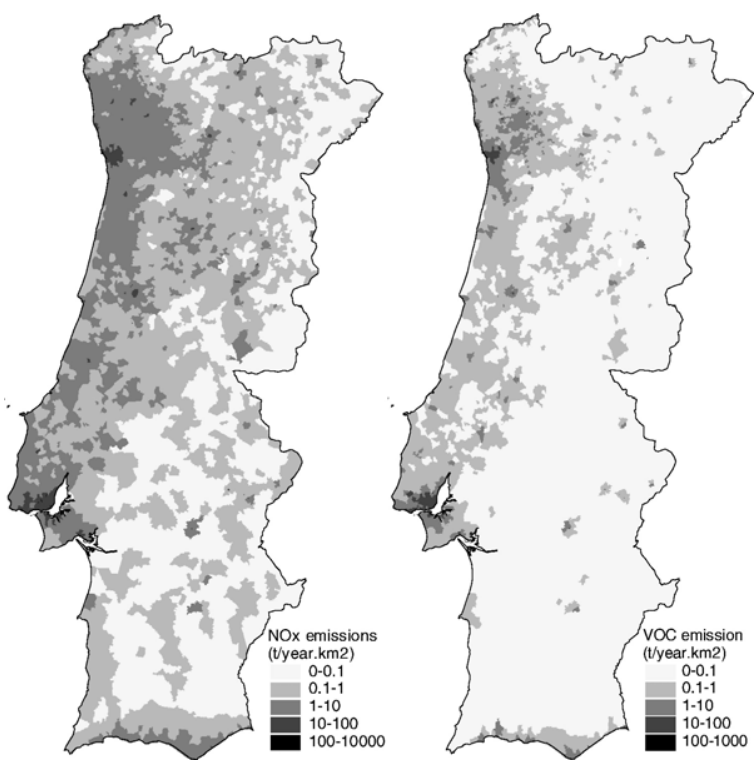

Fig. 3. Spatial distribution of NOx and VOC emissions from area sources. 
Table 1

Limit and target values defined by the European Union directives for $\mathrm{SO}_{2}, \mathrm{NO}_{2}, \mathrm{O}_{3}$, and $\mathrm{CO}$

\begin{tabular}{|c|c|c|c|c|}
\hline Parameters & Period & Air quality standards $\left(\mu \mathrm{g} \mathrm{m}^{-3}\right)$ & No. of allowed exceedances & Target date \\
\hline \multicolumn{5}{|l|}{$\mathrm{SO}_{2}(1999 / 30 / E C)$} \\
\hline Human health protection & Hourly average & 350 & 24 times/year & 1 Jan 2005 \\
\hline Human health protection & Daily average & 125 & 3 times/year & 1 Jan 2005 \\
\hline Vegetation protection & Annual average & 20 & - & - \\
\hline Vegetation protection & Winter average & 20 & - & - \\
\hline \multicolumn{5}{|l|}{$\mathrm{NO}_{2}(1999 / 30 / E C)$} \\
\hline Human health protection & Hourly average & 200 & 18 times/year & 1 Jan 2010 \\
\hline Human health protection & Annual average & 40 & - & 1 Jan 2010 \\
\hline \multicolumn{5}{|l|}{ CO $(1999 / 30 / E C)$} \\
\hline Human health protection & $8 \mathrm{~h}$ running average & $10 \mathrm{mg} \mathrm{m}^{-3}$ & - & 1 Jan 2005 \\
\hline \multicolumn{5}{|l|}{$O_{3}(1999 / 30 / E C)$} \\
\hline Human health protection (target value) & $8 \mathrm{~h}$ running average & 120 & 25 times/year & 1 Jan 2010 \\
\hline $\begin{array}{l}\text { Vegetation protection } \\
\text { (AOT40 target value) }\end{array}$ & Hourly average (May-July) & $18000 \mu \mathrm{g} \mathrm{m}^{-3} \mathrm{~h}$ & - & 1 Jan 2010 \\
\hline Information threshold & Hourly average & 180 & - & - \\
\hline Alert threshold & Hourly average & 240 & 3 consecutive $\mathrm{h}$ & - \\
\hline
\end{tabular}

ethene, propene, isoprene, $a$-pinene, $o$-xylene, formaldehyde, acetaldehyde, and methyl ethyl ketone. For European scale, emissions were derived from the annual totals of the EMEP database for 1999 through a methodology similar to that described in Schmidt et al. (2001).

Over the Portuguese domain, area source (namely transport, combustion and industrial processes, waste treatment, and agriculture) data were obtained following different methodologies as described in Monteiro et al. (2005b). Examples of the estimation of spatial distribution of emissions [NOx and volatile organic compounds (VOC)] from this approach are shown in Fig. 3. Both maps show that most of the emissions are concentrated along the western coast of Portugal, where the two main urban centers of Lisbon and Porto are located. The traffic sector represents, compared to industrial activities, a major source of air pollution (Borrego et al., 2002).

Large point source annual emissions were obtained directly from the available monitoring data of each industrial plant. Time disaggregation was calculated by application of monthly, weekly, and hourly profiles obtained in the scope of GENEMIS Project (GENEMIS, 1994). The non-methane volatile organic compounds (NMVOCs) are disaggregated into 227 individual VOCs according to the speciation suggested by Passant (2002) for each activity sector referred above. The methodology for biogenic emissions of isoprene and terpenes is described in Schmidt et al. (2001). The land use database comes from the Global Land Cover Facility (Hansen et al., 2000), which, after some processing, provides the cell-by- cell coverage of coniferous and broadleaf forests. The spatial distribution of tree species within these classes is established following the methodology outlined in Simpson et al. (1999). The Stohl et al. (1996) methodology is used for biogenic emissions of NO from fertilized soils.

\section{Model validation}

The FWD and daughter directives establish requirements for air quality modelling, including the definition of the Modelling Quality Objectives, as a measure of acceptability of modelling results. In this context, the uncertainty for modelling and objective estimation is defined as the maximum deviation of the measured and calculated concentration levels, over the period for calculating the appropriate threshold, without taking into account the timing of the events. The quality objectives defined for each quality indicator are listed in Table 1.

The model quality measure described in the EU directives is interpreted as the maximum error without timing. For the cases where the absolute maximum error is calculated at the highest percentile, that is, at the highest measured value, the assessment of the model accuracy depends on the model performance in a concentration range associated with an extremely small probability. This also means that the model accuracy assessment can be based on an outlier concentration, caused by an error of the monitoring unit or an extreme weather situation. Therefore, an alternative model error measure is proposed by Stern and Flemming (2004), which is defined as the 
Table 2

Relative error estimation for each pollutant legislative percentile, considering an average of all the monitoring stations

\begin{tabular}{|c|c|c|}
\hline Pollutant & Legislated indicators & $\begin{array}{l}\text { Relative } \\
\text { error }(\%)\end{array}$ \\
\hline \multirow[t]{4}{*}{$\begin{array}{c}\mathrm{SO}_{2} \text { (EU directive } \\
1999 / 30 / \mathrm{EC})\end{array}$} & $\begin{array}{l}\text { Human health protection } \\
\text { (25th maximum hourly average) }\end{array}$ & 34 \\
\hline & $\begin{array}{l}\text { Human health protection } \\
\text { (fourth maximum daily average) }\end{array}$ & 57 \\
\hline & $\begin{array}{l}\text { Vegetation protection (annual } \\
\text { average) }\end{array}$ & 43 \\
\hline & $\begin{array}{l}\text { Vegetation protection } \\
\text { (winter average) }\end{array}$ & 54 \\
\hline \multirow[t]{2}{*}{$\begin{array}{c}\mathrm{NO}_{2} \text { (EU directive } \\
1999 / 30 / \mathrm{EC})\end{array}$} & $\begin{array}{l}\text { Human heath protection } \\
\text { (19th maximum hourly average) }\end{array}$ & 48 \\
\hline & $\begin{array}{l}\text { Human heath protection (annual } \\
\text { average) }\end{array}$ & 50 \\
\hline $\begin{array}{l}\text { CO (EU directive } \\
2000 / 69 / \mathrm{EC})\end{array}$ & $\begin{array}{l}\text { Human health protection } \\
\text { ( } 8 \mathrm{~h} \text { running average) }\end{array}$ & 32 \\
\hline \multirow[t]{2}{*}{$\begin{array}{c}\mathrm{O}_{3} \text { (EU directive } \\
2002 / 3 / \mathrm{EC})\end{array}$} & $\begin{array}{l}\text { Human heath protection } \\
\text { (26th maximum } 8 \mathrm{~h} \text { daily average) }\end{array}$ & 16 \\
\hline & Vegetation protection (AOT40) & 49 \\
\hline
\end{tabular}

concentration difference at the percentile threshold corresponding to the allowed number of exceedence of the limit value normalized by the observation. This relative error (rel_per_err) can be defined by the following expression, where $\mathrm{Op}$ and $\mathrm{Sp}$ represent the observations and calculations, respectively, for each percentile threshold legislated:

rel_per_err $=\frac{|\mathrm{Op}-\mathrm{Sp}|}{\mathrm{Op}}$

In this way, this measure is more robust than the error defined in the EU directive and also evaluates the model performance in the high-concentration ranges, but without the sensitivity to outliers. Following these data quality objectives, a relative error at each legislated percentile threshold was calculated for each air quality background-monitoring site from the national air quality-monitoring network (a total of 15 stations located mainly near the urban centres of Porto and Lisbon), to evaluate model performance for the main critical pollutants. Traffic stations were excluded from this statistical analysis because the model resolution used in this application $\left(10 \times 10 \mathrm{~km}^{2}\right)$ is not representative for those monitoring sites. Table 2 presents the relative error average for all the monitoring sites, for each pollutant parameter defined by the respective daughter directive.

The analysis of Table 2 shows that the model system is able to reproduce the various legislated percentiles, because the relative error measure complies with the accuracy requirement of $50 \%$ for almost all the pol- lutants' limit thresholds. An analysis by pollutant species indicates that ozone presents lower deviations. This fact could be expected because ozone is a secondary pollutant, not directly influenced by emissions as the $\mathrm{NO}_{2}$ pollutant. Besides that, the gas-phase version of the CHIMERE model applied in this study (the aerosol version is still under testing for Portugal) was specially developed to simulate oxidant pollutants and photochemistry and did not include the aerosols' chemistry, which could justify the noncompliance of some parameters for the $\mathrm{SO}_{2}$ pollutant.

Besides this quantitative model evaluation, a qualitative comparison between the modelling results and the average concentrations of $\mathrm{NO}_{2}$ and $\mathrm{O}_{3}$ obtained in a diffusive sampling experimental campaign that took place during two weeks of 2001 (7-21 May and 21-29 June) was performed. This sampling campaign (Ferreira et al., 2001) covered the entire Portuguese continental territory with a sampling diffusive points distribution, within a spatial grid of $20 \times 20 \mathrm{~km}^{2}$ resolution, enabling a broader spatial distribution of $\mathrm{NO}_{2}$ and $\mathrm{O}_{3}$ over Portugal than the one represented by the national air quality network. The measured values represent weekly averaged concentrations. Fig. 4 presents the comparison between the observed and modelled (at first vertical level) $\mathrm{NO}_{2}$ averaged values over the first sampling week and their spatial distribution, showing a relatively good correspondence and a satisfactory model performance. Nevertheless, the model overestimates the $\mathrm{NO}_{2}$ average concentrations in specific areas. In fact, some of these sites correspond to large point source locations, suggesting that the emissions from these industrial sources were introduced in a lower layer of the model, neglecting the plume rise effect. Also, the modelled average of the metropolitan areas of Lisbon and Porto is higher than the observed. This could be justified by an overestimation of the emission inventory for these particular areas (Borrego et al., 2002).

Regarding ozone, the average concentration maps show some discrepancies between the experimental campaign data and the modelling results (Fig. 5), especially in areas not covered by the national monitoring network, such as the north and southeast region. In fact, taking into account that the wind direction during this specific period had a strong east component, in opposition to the N-NW dominant wind direction, this could be due to a lack of knowledge about the emission inventory of Spain (namely point sources emissions) and a consequent underestimation of the boundary conditions in that part of the domain. This hypothesis is under investigation through a scientific collaboration established between research groups of Spain (Galicia) and Portugal. 


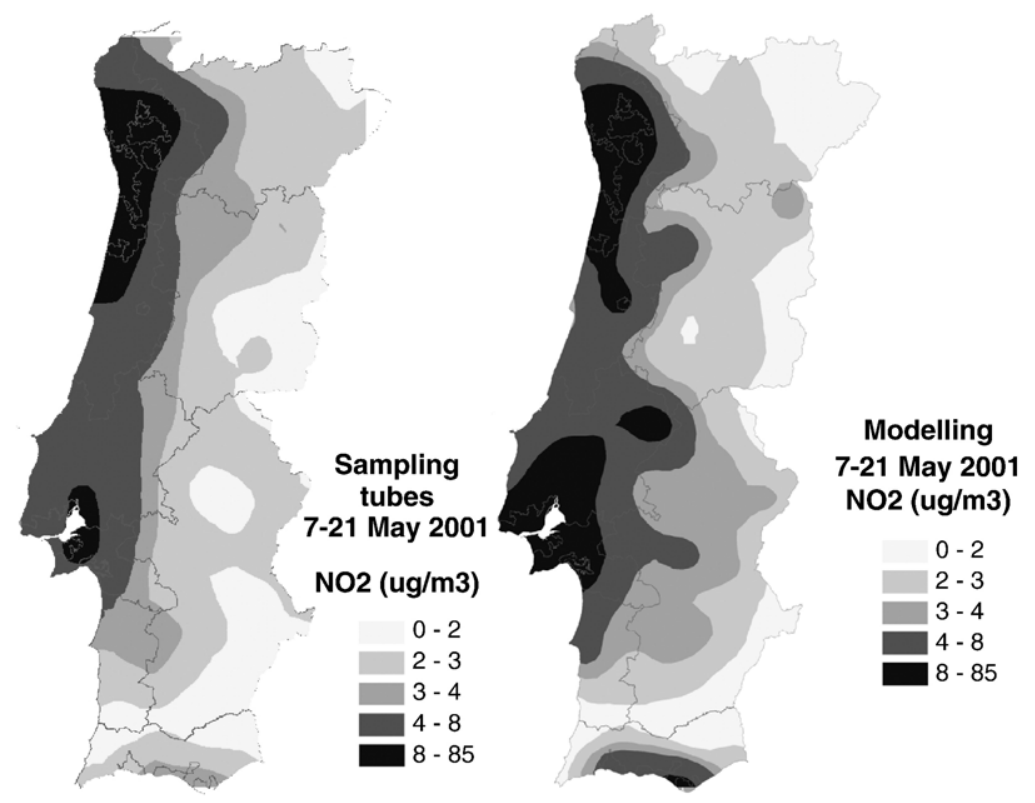

Fig. 4. Weekly averaged concentration maps of $\mathrm{NO}_{2}$ resulting from sampling tubes campaign (Ferreira et al., 2001) and numerical modelling simulations during the period of 7-21 May 2001.

Nevertheless, it remains a good model performance for the major part of Portugal, especially where the monitoring stations from the national network are mainly located, confirmed by the statistical validation presented in Monteiro et al. (2005b) with correlation coefficients of 0.7 and errors less than $30 \mu \mathrm{g} \mathrm{m}^{-3}$ for ozone.

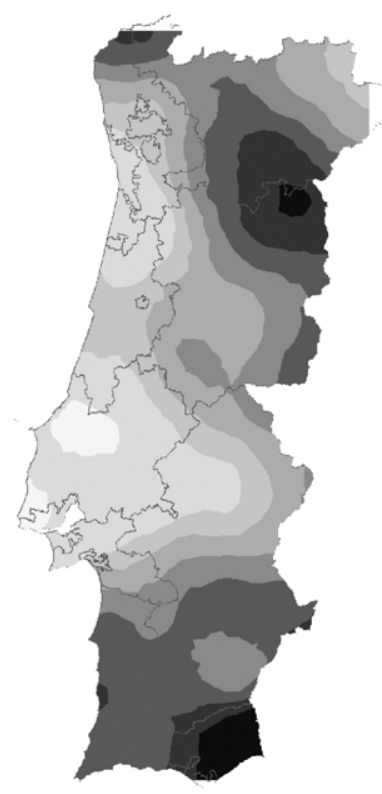

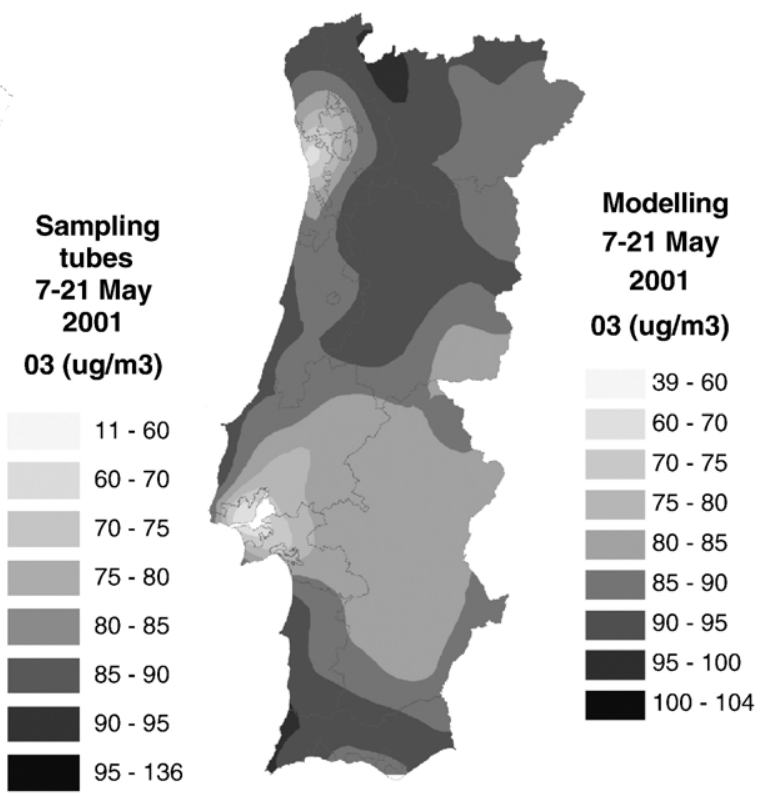

\section{Results and discussion}

The model validation exercise for 2001 initiated in Monteiro et al. (2005b) and developed in the present work shows a model system able to simulate the gaseous pollutants and to perform the first air quality assessment

Fig. 5. Weekly averaged concentration maps of $\mathrm{O}_{3}$ resulting from sampling tubes campaign (Ferreira et al., 2001) and numerical modelling simulations during the period of 7-21 May 2001. 


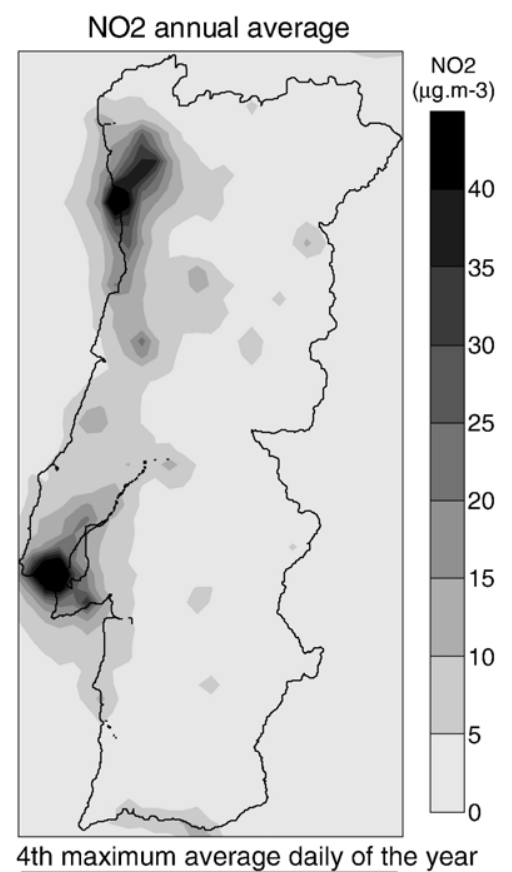

19th maximum hour of the year

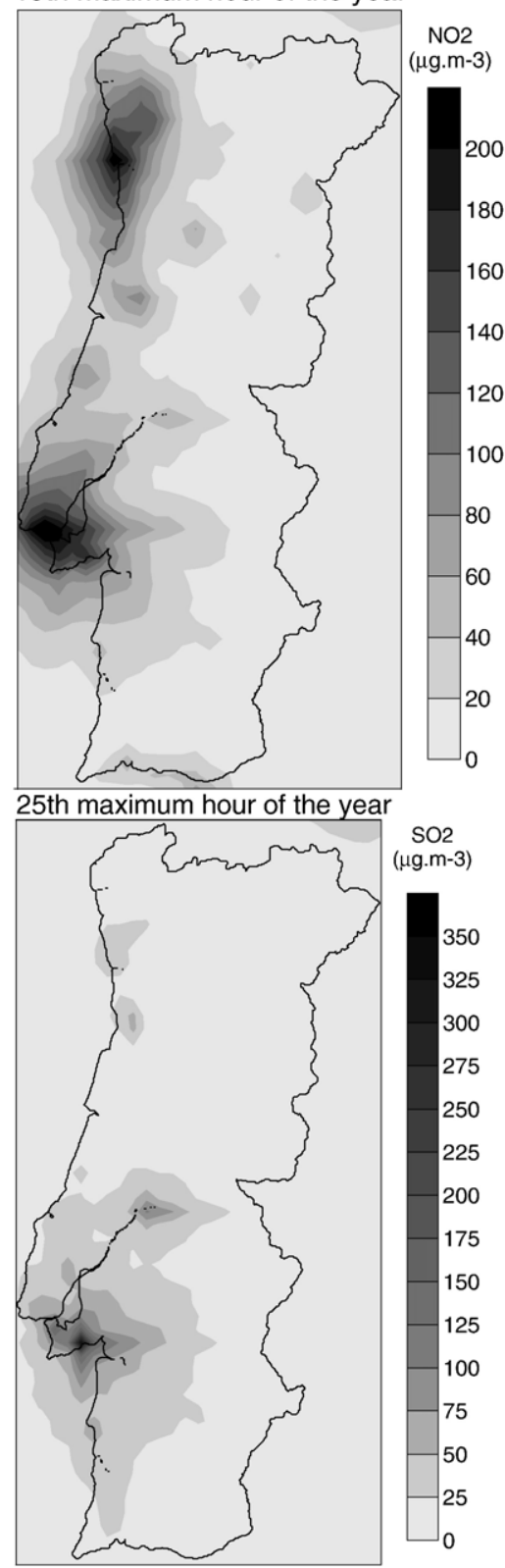

Fig. 6. Modelling results for $\mathrm{NO}_{2}$ and $\mathrm{SO}_{2}$ considering human health protection limits for the year 2001 .

for Portugal. The modelling results for 2001 were analyzed according to the limit and target values defined by the EU directives for each pollutant considered in this study (namely $\mathrm{SO}_{2}, \mathrm{NO}_{2}, \mathrm{CO}$, and $\mathrm{O}_{3}$ ). Fig. 6 presents the modelling results, for 2001, for the legislation indicators of human health protection regarding $\mathrm{NO}_{2}$ (annual average and 19th maximum hour of the year) and $\mathrm{SO}_{2}$ (fourth maximum daily average and the 25 th maximum hourly average).
With regard to $\mathrm{NO}_{2}$, there are areas presenting values exceeding the limit parameters, which correspond to the main urban areas of Portugal: Porto and Lisbon metropolitan regions. Because the remaining area does not present any critical values, this suggests that road traffic is the main activity responsible for the above-mentioned high concentrations of $\mathrm{NO}_{2}$. The modelling results related to $\mathrm{SO}_{2}$ show that there are two areas where the concentrations exceeded the limit values, identified as 

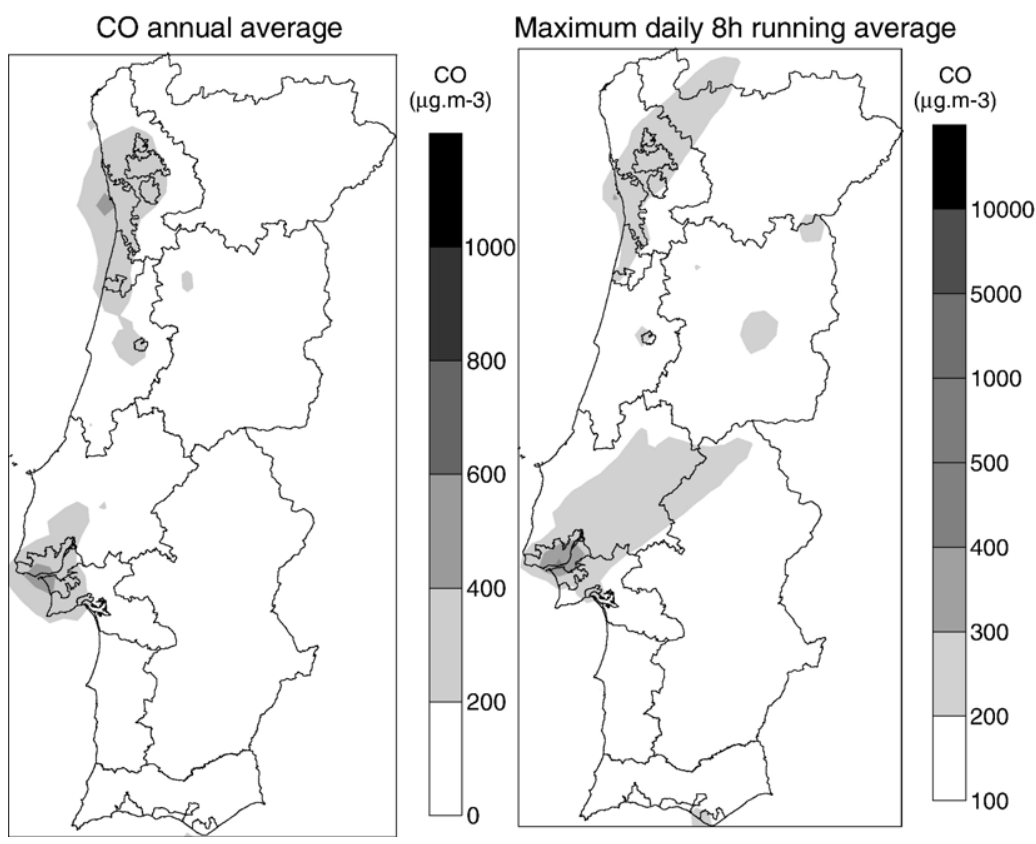

Fig. 7. Modelling results for the annual average and maximum daily $8 \mathrm{~h}$ running average (human health protection limit) of CO for the year 2001 .

industrial places, which suggests that the industry activity is the main factor responsible for the bad air quality in these areas.

For $\mathrm{CO}$, the legislation establishes a maximum of $10 \mathrm{mg} \mathrm{m}^{-3}$ for the daily $8 \mathrm{~h}$ running averages for human health protection. Fig. 7 presents the $\mathrm{CO}$ annual average and the daily $8 \mathrm{~h}$ average concentration patterns. It is possible to verify that there are no areas with concentrations higher than this limit. In fact, the simulation results indicate very low annual average concentrations $\left(200-1000 \mu \mathrm{g} \mathrm{m}^{-3}\right)$ for this pollutant for the entire region of Portugal. This was already expected and
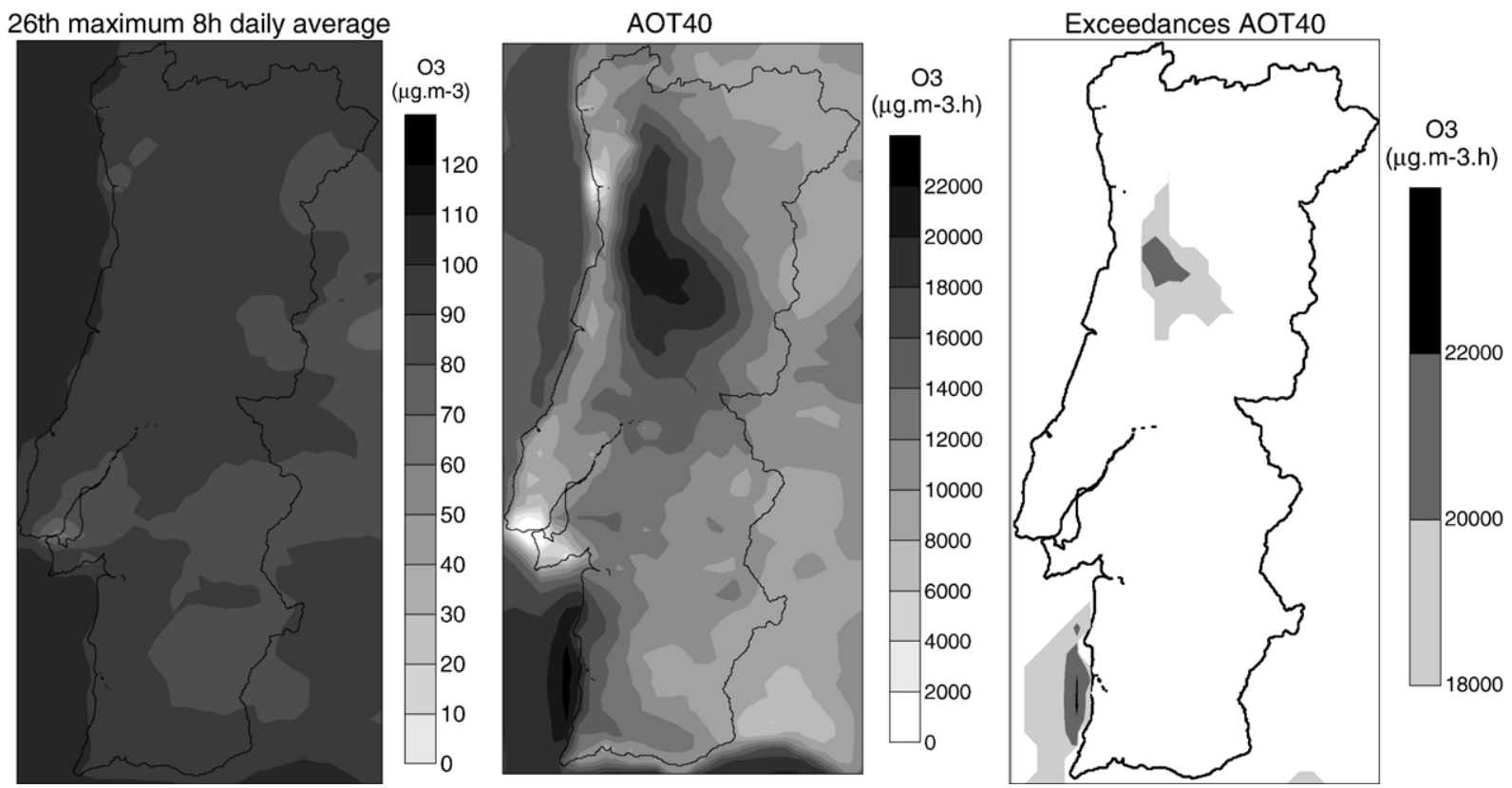

Fig. 8. Modelling results for $\mathrm{O}_{3}$ human health and vegetation protection limits for the year 2001 . 
confirms the modelling and experimental studies that point out $\mathrm{CO}$ concentrations of $0.2 \mathrm{mg} \mathrm{m}^{-3}(150 \mathrm{ppb})$ in remote sites of Europe and values of $1-10 \mathrm{mg} \mathrm{m}^{-3}$ in urban areas (Pfister et al., 2004).

The third daughter directive (2002/03/EC), concerning ozone, defines the target value of $120 \mathrm{\mu g} \mathrm{m}^{-3}$ for the 26th maximum $8 \mathrm{~h}$ daily average and a maximum of $18,000 \mu \mathrm{g} \mathrm{m}^{-3} \mathrm{~h}$ for the AOT40 value. Fig. 8 presents the modelling ozone concentration fields for these two parameters.

Despite the fulfilment of the target value for human health protection $\left(120 \mu \mathrm{g} \mathrm{m}^{-3}\right)$ for the entire national territory, there is some risk for vegetation protection in areas with values exceeding the AOT40 threshold. Unfortunately, according to the land use map, these areas correspond to high-density vegetation and forest areas. These ozone concentration patterns were already foreseen in previous mesoscale modelling studies (Barros et al., 2003; Borrego et al., 2000), where the ozone precursors transport from the urban areas of Porto and Lisbon to the south and interior part of Portugal (by the $\mathrm{N}-\mathrm{NW}$ dominant winds) is clear and significant.

\section{Conclusions}

This work aimed to assess air quality in the continental part of Portugal, according to the requirements of the new FWD air quality. This first assessment exercise was made for the year 2001, using the CHIMERE chemistry-transport model. The model system was evaluated by comparison with observational data obtained from the regional air quality monitoring networks for the main critical gaseous pollutants $\left(\mathrm{NO}_{2}, \mathrm{SO}_{2}, \mathrm{CO}\right.$, and $\mathrm{O}_{3}$ ). The estimated errors in this validation exercise are relatively small and below the limits established by legislation for model evaluation.

With regard to the fulfilment of the thresholds defined by each daughter directive, the modelling results show that there are values exceeding the human health protection limit for $\mathrm{NO}_{2}$ in the two main urban areas (Porto and Lisbon), probably due to road traffic emissions. In comparison, for $\mathrm{SO}_{2}$, the concentration fields indicate some small areas with higher values (higher than the human health limit), all of them located close to large point sources (power plants, more precisely). Ozone is another pollutant with areas exceeding the legislated target values, in what concerns vegetation protection. These areas are mainly located in the inland central part and southwest coast of Portugal, not covered by the air quality monitoring networks. $\mathrm{CO}$ is the unique pollutant that accomplishes the limits imposed by legislation, with concentration values significantly low in the entire study domain.
This first air quality assessment work for Portugal enabled to verify the importance of the establishment of several target values for each air pollutant. In fact, the fulfilment of one of these limits does not imply the accomplishment of all, as confirmed by the $\mathrm{O}_{3}$ results. Future work will focus on the other critical pollutants, namely $\mathrm{PM}_{10}$, and will evaluate the CHIMERE aerosols version for this specific coastal area. Besides that, simulations on urban scale for Lisbon and Porto domains will be performed, with a higher-scale resolution $\left(2 \times 2 \mathrm{~km}^{2}\right)$, to evaluate more correctly the air quality problems in these regions, identified as the main critical areas, and influenced by traffic emissions and local conditions.

\section{Acknowledgements}

The authors wish to thank the Portuguese Institute for the Environment for financing and giving access to measured data, and to the financial support of the third EU Framework Program and to AIR4EU project (SSPI/ CT2003/503596). Thanks are extended to the Portuguese Ministério da Ciência e do Ensino Superior, for the $\mathrm{PhD}$ grant of A. Monteiro (SFRH/BD/10922/2002). The authors are also grateful to the Network of Excellence ACCENT (GOCE-CT-2004-505337).

\section{References}

Barros N, Borrego C, Toll I, Soriano C, Jiménez P, Baldasano JM. Urban photochemical pollution in the Iberian Peninsula: Lisboa and Barcelona airsheds. Air Waste Manage Assoc 2003;53:347-59.

Beekmann M, Derognat C. Monte Carlo uncertainty analysis of a regional-scale transport chemistry model constrained by measurements from the Atmospheric Pollution Over the Paris Area (ESQUIF) campaign. J Geophys Res 2003;108(D17):8559.

Borrego C, Barros N, Miranda AI, Carvalho AC, Valinhas MJ. Validation of two photochemical numerical systems under complex mesoscale circulations. In: Gryning S, Batchvarova E, editors. 23rd International technical meeting on air pollution modelling and its application, September 28-October 2 1998, Varna, Bulgaria. New York: Kluwer Academic/Plenum Publishers; 2000. p. 597-604.

Borrego C, Tchepel O, Monteiro A, Barros N, Miranda A. Influence of traffic emissions estimation variability on urban air quality modelling. Water Air Soil Pollut 2002; Focus 2 (5-6):487-499.

Coutinho M, Borrego C. Photochemical production on coastal areas of Portugal. 19th Int. tech. meeting of NATO-CCMS on air pollution modeling and its applications, 29 Sept. -4 Oct., Ierapetre, Crete. Kluwer Academic/Plenum Publishers; 1991. p. 129-36.

Derognat C, Beekmann M, Baeumle M, Martin D, Schmidt H. Effect of biogenic volatile organic compound emissions on tropospheric chemistry during the Atmospheric Pollution Over the Paris Area (ESQUIF) campaign in the Ile-de-France region. J Geophys Res 2003;108(D17):8560

GENEMIS (Generation of European Emission Data for Episodes) Project. EUROTRAC annual report 1993, part 5. Garmisch-Partenkirchen: EUROTRAC International Scientific Secretariat; 1994. 
Hansen M, DeFries R, Townshend JRG, Sohlberg R. Global land cover classification at $1 \mathrm{~km}$ resolution using a decision tree classifier. Int J Remote Sens 2000;21:1331-65.

Hogrefe C, Rao T, Kasibhatla P, Hao W, Sistla G, Mathur R, et al. Evaluating the performances of regional-scale photochemical modelling systems: part II - ozone predictions. Atmos Environ 2001;35:4175-88.

Horowitz LW, Walters S, Mauzerall D, Emmons L, Rasch P, Granier C, et al. A global simulation of tropospheric ozone and related tracers: Description and evaluation of MOZART, version 2. J Geophys Res 2005;108(D24):4784.

Ferreira F, Tente H, Torres P, Mesquita S, Santos E, Jardim D, et al. Background levels of sulphur dioxide, nitrogen dioxide and ozone in Portugal. International conference measuring air pollutants by diffusive sampling, 26-28 September, Montpelier, France; 2001.

Menut L. Adjoint modelling for atmospheric pollution process sensitivity at regional scale. J Geophys Res 2003;108(D17):8562.

Monteiro A, Vautard R, Lopes M, Miranda AI, Borrego C. Air Pollution Forecast in Portugal: a demand from the new Air Quality Framework Directive. Int J Environ Pollut 2005a;25(2):4-15.

Monteiro A, Vautard R, Borrego C, Miranda AI. Long-term simulations of photo oxidant pollution over Portugal using the CHIMERE model. Atmos Environ 2005b;39:3089-101.

Passant NR. Speciation of U.K. emissions of non-methane VOC, AEAT/ENV/0545 Issue 1; 2002.

Pfister G, Pétron G, Emmons LK, Gille JC, Edwards DP, Lamarque JF, et al. Evaluation of CO simulations and the analysis of the $\mathrm{CO}$ budget for Europe. J Geophys Res 2004;109(19):1-14.
Schmidt H, Derognat C, Vautard R, Beekmann M. A comparison of simulated and observed ozone mixing ratios for the summer of 1998 in Western Europe. Atmos Environ 2001;35:2449-61.

Simpson D, Winiwarter W, Börjesson G, Cinderby S, Ferreiro A, Guenther A, et al. Inventorying emissions from nature in Europe. J Geophys Res 1999;104:8113-52.

Stern R, Flemming J. Formulation of criteria to be used for the determination of the accuracy of model calculations according to the requirements of the EU Directives for air quality. F\&R Project 20143250. Berlin, Germany: Freie Universität Berlin Institut für Meteorologie Troposphärische Umweltforschung; 2004.

Stohl A, Williams E, Wotawa G, Kromp-Kolb H. A European inventory for soil nitric oxide emissions and the effect of these emissions on the photochemical formation of ozone. Atmos Environ 1996;30:3741-55.

Tilmes S, Brandt J, Flatfy F, Bergstrom R, Flemming J, Langner J, et al. Comparison of five Eulerian air pollution forecasting systems for the summer of 1999 using the German ozone monitoring data. J Atmos Chem 2002;42:91-121.

Vautard R, Beekmann M, Roux J, Gombert D. Validation of a deterministic forecasting system for the ozone concentrations over the Paris area. Atmos Environ 2000;35:2449-61.

Vautard R, Martin D, Beekmann M, Drobinski P, Friedrich R, Jaubertie A, et al. Paris emission inventory diagnostics from ESQUIF airborne measurements and a chemistry transport model. J Geophys Res 2003;108:D17:8564. 